Мегатренд универзитет, Факултет за културу и медије, Београд

DOI 10.5937/kultura1338376N

УДК 316.324.8:316.774

005:316.774

прегледни рад

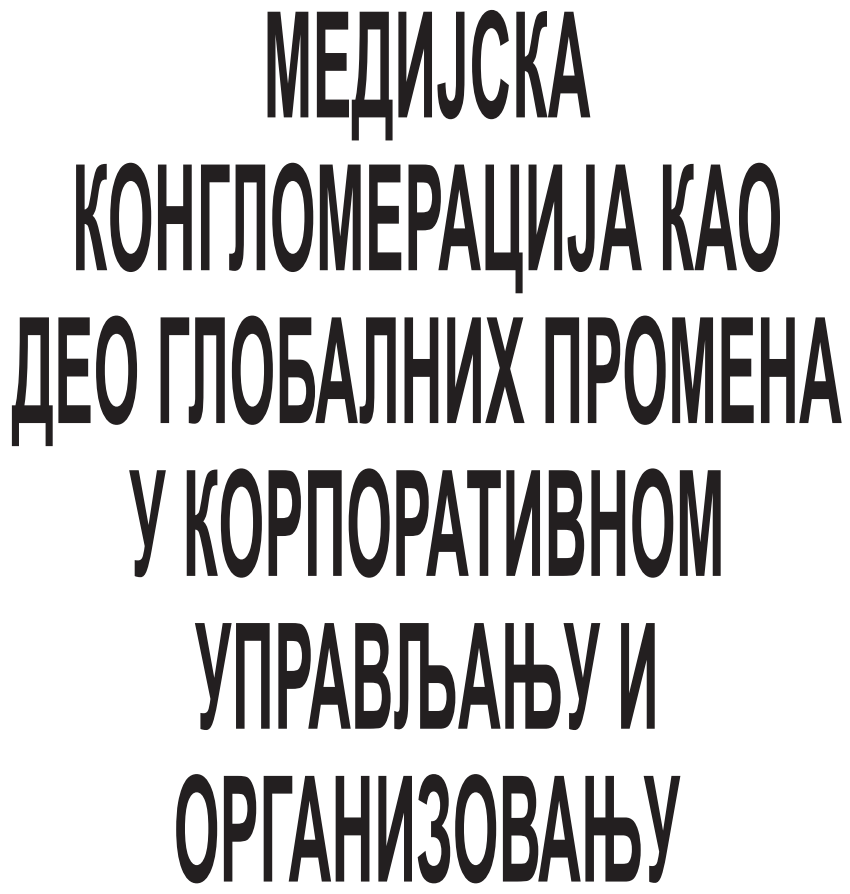

Сажетак: Околност да медији својим комуникацијским потенциијалима ревносно опслужују разнородне глобализачијске процесе није ни нова ни непозната. Мање је међутим уочљиво да медијски систем у све већој мери опонаша глобалне корпоративне обрасие организовања и пословања који подразумевају мултинационално $и$ планетарно распростирање не само медијских утицаја већ и капитала. Људи који раде у медијима, као и они у другим делатностима, суочени су такође са изазовима новог доба.

Кључне речи: глобализачија, медији, економија, пропаганда, медијски конгломерати

Судећи према многобројним, често и међусобно супротстављеним, тумачењима, појмом „Глобализација“ се у времену данашњем означавају разнородни феномени и процеси за које бисмо могли тврдити да задиру у све сегменте 
друштвеног живота. ${ }^{1}$ Од глобализације схваћене као „идеје о свету као јединственој целини“", преко интерпретација које нам указују на природу политичких, економских, културних, еколошких, војних и других промена које се збивају на глобалном плану, па све до тврдих констатација и осуда које о глобализацији говоре као о „лонцу за топљење“ (melting pot) националних посебности.

Како год, оно што нас занима је питање позиције и улоге медија сфере у овим комплексним процесима, односно да ли постоји и каква је по својој природи евентуална корелација глобализације са актуелном праксом масовних медија. Присећањем на Бодријарово питање-констатацију - „Има ли ичега изван медија?“ - чини се да не треба имати никаквих сумњи у постојање чврстих веза и интензивних односа између медијске праксе и садржаја у знаку којих се одвија процес глобализације. Штавише, тешко да бисмо изван медија сфере могли наћи неки сегмент друштвене праксе који тако усрдно и уз то веома ефикасно опслужује процес глобализације. Међутим, околност да се медији инструментализују или стављају у службу владајућих снага или процеса који доминирају одређеним епохама, попут глобализације у ововременој, ни по чему није нова. Пре би се за ову појаву могло тврдити да је она својеврсна константа која обележава укупну историју медија.

Међу многобројним разлозима који су определили такву друштвену, готово се може рећи и историјску, позицију и улогу медија неколики су кључни.

Први се несумњиво везује за ванредне комуникационе моћи медија, које су постале носиоцем разнородних видова дистрибуције утицаја већ од најранијих раздобља снажења медијских потенцијала, односно омасовљавања корисничког домена сваког појединачног медија. Нажалост, уместо да у свему служи друштвеној добробити, медијска пракса готово у самом настајању постаје терен честих идеолошкопропагандних злоупотреба и манипулација. Историјски посматрано, медији се најпре стављају у службу пропагандне афирмације сепаратних циљева (сетимо се употребе медија у доба нацизма) да би се временом њихови утицаји преусмерили на холистички терен подршке „универзалне идеологије новог светског поретка““ или ка промоцији либерализма односно „идеологије слободе као инструмента освајања света““. Овај аспект употребе медија од самих почетака

1 Реализовано у оквиру пројекта МНТР бр. 47004 (подпројекат: „Управљачко-организациона димензија културне, уметничке и медијске праксе као претпоставке одрживог развоја“) 
побуђује велико интересовање, о чему сведоче радови читаве плејаде угледних теоретичара - од Бењамина (Benjamin W.), преко Адорна (Adorno W. Th.) и других представника такозване франкфуртске школе, до Маклуана (McLuhan M.), Бодријара (Baudrillard J.), Чомског (Chomsky), Вирилија (Virilio P.) и тако даље.

У даљем току ствари, (зло)употреба медија се измешта са терена идеолошко-политичких утицаја ка домену економске пропаганде подржавајући на глобалном плану управо оне обрасце из којих економија црпи успех односно профит - продуктивност, исплативост, предвидљивост, контролу... Медијски посредоване маркетиншке комуникације већ деценијама ефикасно промовишу концепт „диктатуре благостања“. Тако се посредством медија здушно гради лажна слика о томе да између економије и бољег живота стоји знак једнакости. Нико се није замислио над чињеницом да је „глобализација у тренутно доминантном облику капитализма слободног тржишта донела (је) такође и спектакуларан и потенцијално експлозиван пораст социјалне и економске неједнакости унутар држава и на међународном плану“2. Врло брзо ће се, наравно, испоставити да материјално стицање и богаћење не нуде духовно и културно уточиште. Најзад, актуелна економска криза ће показати сву неправду која прати прерасподелу економске добити. Стицање и профит су посредством уходаних механизама и канала непрестано персонализовани, док су све недаће и економски губици социјализовани и пренети на најшире друштвене слојеве. Дакле, они малобројни који су се својевремено обогатили данас нам тумаче да је економска криза општа, глобална.

Најзад, услед технологија на којима почива, јефтина, брза и мултипликативна, те тиме подесна за тржишну утакмицу, медијска продукција постаје предметом непосредне економске експлоатације. Медијска пракса прераста у трговински сектор снабдевен каналима за дистрибуцију, комерцијалним и пропагандним средствима, укратко свим елементима једне типичне економске делатности. На тај начин се дакле и сама медијска пракса непосредно придружује и постаје конститутивни део глобалних економских процеса. За разлику од „буке“ којом је у јавности било праћено идеолошко-пропагандно коришћење медија, њихова подршка глобалним економским процесима и у новије доба све интензивнија економска експлоатација медијске праксе се одвија у највећој тишини. Зачудо ове промене нису побудиле

2 Хобсбаум Е., Глобализација, демократија и тероризам, Архипелаг, Београд 2008, стр. 52-53. 
значајнију пажњу теоријских кругова. Теоријска интересовања су и даље остала привржена промишљању медијске феноменологије која се везује за њихове идеолошке и социјалне утицаје.

Сасвим на крају, рекли бисмо да још једно од обележја медија сфере данашњег доба заслужује нашу пажњу у контексту анализе улоге медија у процесима глобализације. Реч је о дигитализацији као технолошкој претпоставци савремених медијских потенцијала која је не само допринела интеграцији и снажењу комуникацијских моћи медија, већ се показала и значајном у креирању нових социјалних и културних образаца који управо погодују „идеји о свету као јединственој целини““.

Оно што је предмет наше елаборације биће ограничено на покушај да се осветле само поједини аспекти који указују на околности прилагођавања медијске праксе потребама глобализацијских процеса. У првом реду ће бити речи о променама и управљачко-организационим корпоративним престројавањима, што ће за последицу имати сродне процесе у медија сфери који ће водити у правцу медијске конгломерације на планетарном односно глобалном нивоу.

\section{Глобални обрасии корпоративног}

\section{управљана и организована}

Идеја о свету као јединственој целини је нужно подразумевала и успостављање управаљачких механизама и организационих структура, које ће функционално подржати њено непосредно остваривање. Традиционални развојни оквир индустријског доба, који је почивао на производњи, потрошњи и институционалном поретку сачињеном од организација, са чврстом унутрашњом пирамидалном структуром, испоставио се као неподесан за реализацију таквих циљева. Новом светском поретку био је потребан нови развојни оквир.

У новом поретку организациони оквир деловања све чешће није чврста, дугорочно пројектована пирамидална структура класичних институција. Институције новог типа немају трајни већ привремени карактер. Нови и подеснији делатни оквир има архитектуру флексибилне организаиије која „може изабрати и извршавати у ма ком тренутку само неке од својих бројних функција““. Нова организациона структура није стабилна и фиксна.

3 Сенет Р., Култура новог капитализма, Архипелаг, Београд 2007, стр. 43. 
Нове организације су у непрестаном трагању за новим и ефикаснијим пословним моделима. Наравно да ће у том процесу најсавременије технологије, посебно оне са комуникацијским потенцијалима, попут интернета на који су ослоњени најразличитији видови такозваног е-пословања, добијати на све већем значају.

Управљање савременим организационим структурама је другачије. Центри управљања новог доба подсећају, каже P. Сенет, на даљински управљач (remote control) или МП3 (media player) уређај који има капацитет да у неком тренутку активира било коју од многобројних функција која ће покренути неки од расположивих ресурса - ма где се он налазио, „зато што централна процесорска јединица контролише целину“4. Велике мултинационалне корпорације располажу различитим ресурсима, њиховим функцијама и потенцијалима на многобројним географским позицијама. Управљачки механизам им омогућава њихово активирање (или гашење) у зависности од актуелних пословних опција. Управљање се, уместо на непосредни увид и „распон контроле“, о чему је говорио Тејлор, ослања на неку врсту „паноптичког надзирања“ (М.Фуко/Fuco) - „људи на периферији самостално обављају посао, нема много интеракције у командном ланцу... “5

Ни сами менаџери нису изузети од правила која ће доминирати управљачким моделом будућности - „Менаџери ће се процењивати по краткорочним мерилима, и остаће на радним местима докле год буду одговарали на очекивања неуједначеног тржишта“"6. Коначне одлуке припадају акционарима који су за запослене још мање видљивији од менаџера - „Акционари из великих друштава постаће све неухватљивији, све хировитији, нелојални, равнодушни на дугорочне захтеве предузећа у која инвестирају, и водиће рачуна само о тренутим преимућствима која могу да извуку“"7.

Између оних који су непосредни извршиоци и управљачких структура „постоји трансакција а не однос. Они на периферији дужни су само да покажу резултате рада онима у центру“8. У пирамидалној структури традиционалних институција, на њеном врху се налазио „очински послодавац“-

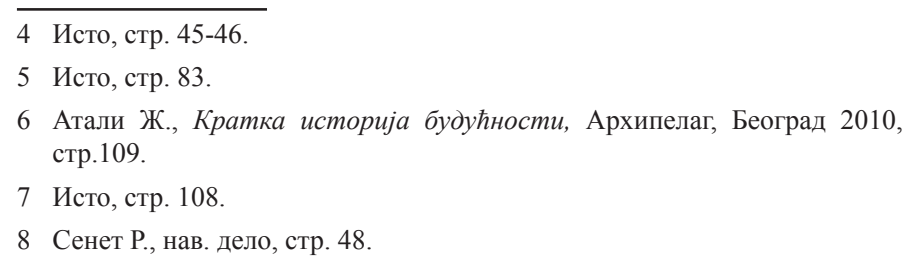


„У социолошком погледу, био им је ближи, као што је генерал на бојном пољу повезан са својим војницима“" .

Промена у позицији оних који управљају, угрозиће још један од виталних принципа традиционалног менаџмента aуторитет. Ауторитет носилаца управљачких функција слаби или се потпуно губи са удаљавањем центара управљања. Њихова невидљива моћ, међутим, расте. То је у потпуној супротности са Фајоловим тумачењем ауторитета, као једног од базичних принципа менаџмента.

Лојалност и оданост организацији неће више бити одлика оних који ће у њима радити. Изгубили су се готово сви разлози за било какав емотиван однос. Запослени су препуштени сами себи и не очекују, као у некадашњем дугорочном односу, да им организација помогне када им помоћ буде била потребна. За разлику од традиционалних организација у чијем су стварању и развоју учествовали, њихово учешће у функционисању нових организација је краткорочно и без могућности увида у целовитост процеса и развојне перспективе. Због лабавих веза запослених са новим организацијама, оне немају више преко потребан соиијални капитал.

Фрагментираност позиције запослених у новим организацијама онемогући ће успостављање чвршћих неформалних веза које воде ка духу заједништва (esprit de corps) - што је принцип менаџмента који је још Фајол идентификовао. Да би се развило узајамно поверење међу запосленима, потребно је време. У организацијама које су оријентисане на краткорочне резултате најчешће нема довољно времена да се формирају блиски односи међу запосленима. Уместо тога, „конкуренција међу радницима, у предузећу и у тражењу посла, биће све већа“"10.

У традиционалном институционалном систему људи су, на темељу искуства стеченог у дугорочним процесима, знали тачно шта се од њих очекује. Задовољство су налазили у томе да буду корисни и себи и другима. Искуство, које је некада било веома цењени резултат дугорочног ангажмана и темељ стицања вештина, изгубило је на вредности. Нови управљачки приступ није заинтересован за „ментални склоп оријентисан на прошлост, али без лекција из историje“ (Џ.Несбит/Naisbitt) јер он спутава могућност сагледавања промена. Отуда равнодушност према искуству и „одумирање вештина представља трајну одлику технолошког

9 Исто.

10 Атали Ж., нав. дело, стр. 108. 
напретка“"11. Овде, наравно, не треба заборавити да је високо вредновање искуства у традиционалном индустријском поретку узроковало и својеврстан парадокс - искуство нећете стећи док се не запослите, а не можете се нигде запослити без искуства.

Нове околности нису увек ни сасвим очигледне ни свима разумљиве, што за последицу често има ставове и понашања који нису усклађени са захтевима новог доба. Да би се ови проблеми отклонили, по свему судећи је потребно време које ће формирати једну другу врсту организационе културе која је блиска већини, а не само највишим управљачким функцијама - „Попут свих култура, и култура фирме зависи од тога како обични људи схватају институцију, а не од објашњења које у виду указа долази с врха“"12. Међутим, с обзиром да нас очекује будућност карактеристична по свеопштој „несташици времена“, неће бити довољно времена да сви кроз прилагођавање добију своју шансу.

Шта се очекује од оних који ће имати шансу да се прилагоде и тако избегну да се нађу у вишковима тржишта радне снаге и да постану учесници и актери нових делатних процеса?

Већ су технички проналасци и употреба машина у индустријском добу изместили човека из средишње позиције у производном процесу. Његова улога је престала да буде одлучујућа већ постаје придодата и споредна, јер главне производне функције преузимају машине. Даљим технолошким напретком ова ситуација се само продубљује. У најновијим, аутоматизованим, компјутеризованим, роботизованим, дигитализованим... технолошким процесима, учешће самог човека и непосредног људског рада се све више смањује - '“Садржај рада у индустријској производњи опада драматично: 1970 . је био око $25 \%$; данас је око $4 \%$ “"13.

Последица тога је да „више нема ни капиталистичких корпорација које су запосленима доживотно обезбеђивале посао, а потрошаче из године у годину снабдевале истим производима и услугама“"14.

Оно што је најчешће видљива последица изазова и околности новог доба јесте да у новим облицима организовања запослени врло често не знају шта се од њих тачно очекује.

11 Сенет Р., нав. дело, стр. 94.

12 Сенет Р., нав. дело, стр. 61.

13 Несбит Џ., Ментални склоп-промени оквир и сагледај будћност, Мегатренд универзитет, Београд 2009, стр.175.

14 Сенет Р., нав. дело, стр. 175. 
Да ли потенцијалне способности које раскидају са искуством и стеченим вештинама припадају емотивној интелигениији, категорији која се све чешће помиње у теоријским круговима менаџмента? Да ли је то способност да се мисли о новим могућностима изван искуственог контекста, с ослонцем на имагинацију; способност да се чује намера у позадини нечијих речи...? Можда се има у виду урођена, природна способност која није свима дата!?

Један од приступа, који је по свему судећи изнудила сурова пракса савременог пословања, почива на принципима соиијалног дарвинизма. Он у себи садржи „закон о мањини виталних“, односно „модел виталности“ сликовито представљен као „20-70-10“, по којем је 20 одсто оних који су врхунски продуктивни, 70 одсто „ради колико треба“, а 10 одсто су непродуктивни. Систем модерног вредновања познат као rank and yank (успеваш или нестајеш) односно ир or out, менаџерима је често путоказ у вођењу пословне политике.

\section{Медијска конгломерачија - управљачко- организационо реструктурирање медија сфере у глобалном поретку}

Стиче се утисак да се обриси „новог поретка“ у оквиру модела управљања и организовања најинтензивније наслућују или помаљају управо у медијској сфери.

Медијска делатност, која свој настанак и развој дугује научно-технолошком напретку, вођена економском логиком и тржишним закономерностима, својевремено је у великој мери следила и усвајала управљачко-организационе обрасце карактеристичне за индустријске облике производње. Медиј штампе је, као што знамо, захваљујући парном, потом и електричном погону и техничком изуму ротационих штампарских машина, већ у 19. веку у потпуности индустријализовао своју делатност, и тој околности прилагодио облике организовања и управљачке механизме. Рецимо, подела на „беле, плаве и шарене крагне“ води порекло из делатности новинских предузећа и говори о унутрашњој хијерархијској структури која је сродна оној у индустријским организацијама. Кинематографија се, исто тако, врло брзо, од техничког проналаска и забаве маса, трансформисала у продукцију организовану и вођену у складу са индустријским начелима. Већ у другој деценији прошлог века, холивудски студији, у организацији и управљању, опонашају индустријске погоне. Друго име Холивуда - „фабрика снова“ - о томе најбоље сведочи. Велика тражња за филмовима 
и могућност стицања профита „навела је продуценте да с филмом поступају као са сваким другим индустријским производом. Они су, другим речима, и на филм применили, без икакве промене, оне продуцентске облике који су се на почетку XX века развили у другим економским секторима“"15. Дакле, управо је медијска пракса у великој мери опонашала владајуће обрасце управљања и организовања индустријског доба.

Уместо у производњи и потрошњи индустријских роба, ново доба за развојним перспективама трага у оквирима производюе и промета информаиијама. У складу са таквим препознавањем водећих друштвених потенцијала, централно место све мање припада фабрикама и хипермаркетима, а све више образовним и информационо-комуникационим системима, то јест медијима.

Отуда су глобалне промене, које су се догодиле и које се догађају у савременом друштвеном амбијенту, најуочљивије управо у медијском сектору.

Иновације у комуникационим технологијама представљају најзначајнији искорак од индустријског ка постиндустријском концепту. Оне су, разумљиво, поново највиши степен примене оствариле у оквиру делатности медија - радио, телевизија, видео, рачунари, интернет... Ове технологије, поготово у својим најсавременијим дигиталним изведбама, све мање припадају индустријском концепту. Оне су по много чему ближе увелико наступајућем постиндустријском и информатичком добу.

Логично је претпоставити да новом информатичком добу, којем управо печат даје технолошки (и садржајно) иновирана медијска сфера, нису више сасвим блиски обрасци организовања и управљања карактеристични за индустријско раздобље. Стари обрасци се напуштају и мењају, али те промене нису ни брзе ни лако уочљиве. Без обзира што тежи променама и увођењу другачијих облика живљења и рада, свака нова епоха се споро и тешко одриче и удаљава од свикнутих и уходаних образаца на којима се темељила дојучерашња егзистенција. Штавише, склона је да их брани и одржава по сваку цену, све до часа у којем њихов опстанак постаје немогућ. До тренутка дефинитивних промена стари и нови обрасци, уз присуство различитих мутација, живе паралелно, једни поред других.

15 Бехлин П., Филм као роба, Завод за уџбенике и наставна средства, Београд 2002, стр. 28. 
Да ли је, ипак, могуће сагледати неке од глобалних промена које се тичу управљања и организовања у медијској сфери?

Развој медијске сфере непрестано протиче у знаку процеса конвергенције односно узајамног приближавања медија. Успостављање јединствене дигиталне технолошке основе омогућиће даљи корак у том правцу - спајање медија односно медијске интеграције. У технолошком смислу, медијска интеграција подразумева различите, али дигитализоване сигнале, односно спајање различитих типова медија као што су текст, слике, графике, видео, филм, говорне поруке или звучне секвенце. Сигнали се у дигитализованој форми сједињују преко рачунарске технологије, која их, уз одговарајући хардвер и софтвер, прима, чува, обрађује или демонстрира.

Ова промена нема само технолошку него и управљачко-организациону димензију. Она се препознаје у медијској концетрацији, било као новом облику медијског пословања или новом виду власништва медија. Медијске концентрације попримају најразличитије форме.

Националне границе постају тесан пословни и организациони оквир за деловање новонасталих мултимедијских конгломерата. Прекогранични проток медијских садржаја је главна карактеристика њиховог тржишног наступа. Број ових мамутских организација није велики, али њихов утицај и удео на медијском тржишту јесте - „новоуспостављеним глобалним медијским системом доминира тридесет или четрдесет великих транснационалних корпорација (ТНЦ), од којих су десетак конгломерати са седиштем у САД, који надзиру глобално тржиште“16. Такозвана „велика петорка“ тренутно држи више од половине свих медија на планети - Time Warner, News Corporation, Viacom, The Walt Disney Company и Bertelsmann. Тиме се наравно не исцрпљује списак медијских конгломерата - следе их PolyGram, Seagram, Sony, General Electric, Tele-Comunications Inc (TCI), Thomson Corporation (Канада), Westinghouse, Dow Jones, Gannem, The New York Times, BBC, Reuters, CEP Communications (Француска)... Присуство великих конгломерата је све израженије и у нашој медијској средини. За сада су ту, један од највећих у свету, News Corporations, и два мања европска - WAC и Ringier.

Процес конгломерације и куповина мањих медијских организација од стране великих, што се често одвија по моделу такозваног „непријатељског преузимања“, није окончан.

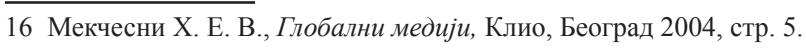


Не треба сасвим искључити могућност да у блиској будућности дође и до фузије у оквиру „велике петорке“, те да о информисаности, култури и забави, дакле духовном животу читаве планете, одлучује само један човек. У историјском смислу то и не би представљало посебну новину - „У сваком друштву дух читаве културе одређен је духом најмоћнијих“"17. У сваком случају, можемо закључити да последице промена које се догађају или ће се тек догодити у медијској сфери могу бити знатно дубље и далекосежније од оних у сфери економије.

Уколико се ови процеси наставе, земље које у свом развоју заостају са укључивањем у утакмицу која се води у „глобалном информатичком друштву“, суочиће се са још озбиљнијим проблемима - „земље, са извесним заостатком у развоју, излажу се опасности да буду ометене и у развоју сопствених култура... Тај ризик је толики да у неким земљама може да доведе и до уништења традиционалног идентитета и свих његових културних обележја“"18. Исто тако, „глобализација и децентрализација воде нас све даље од света националних држава према свету економских домена, не као новом начину организовања света већ као новом начину схватања света“"19.

\section{ЛИТЕРАТУРА:}

Атали Ж., Кратка историја будућности, Архипелаг, Београд 2010.

Бехлин П., Филм као роба, Завод за уџбенике и наставна средства, Београд 2002.

Фајол А., Општи и индустријски менаимент, Адижес центар, Нови Сад 2006.

Фром Е., Бекство од слободе,Напријед, Загреб и Нолит, Београд 1984.

Ирис А., Информационе магистрале, Клио, Београд 1999.

Несбит Д., Ментални склоп - промени оквир и салледај будућност, Мегатренд, Београд 2009.

Никодијевић Д., Менаимент масовних медија - штампа, филм, радио, телевизија и интернет, Чигоја штампа, Београд 2012.

Сенет Р., Култура новог капитализма, Архипелаг, Београд 2007.

Херман Е. М. В., Глобални медији, Клио, Београд 2004.

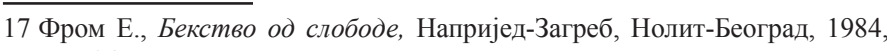
стр. 84.

18 Антоан И., Информационе магистрале, Клио, Београд, 1999, стр. 49-50.

19 Несбит Џ., Ментални склоп-промени оквир и сагледај будућност, Мегатренд универзитет, Београд 2009, стр.175. 
Dragan Nikodijević

Megatrend University, Faculty for Culture and Media, Belgrade

\title{
THE MEDIA CONGLOMERISATION AS PART OF GLOBAL CHANGES IN CORPORATIVE MANAGEMENT AND ORGANIZATION
}

\begin{abstract}
The circumstance of having the media ardently serving various sorts of globalization processes is neither new nor unknown. However, it is less obvious how the system of the media growingly mimics global corporative ways of organizing and leading business, which includes multinational and planetar widespread of not only media influences but capital influences as well. People who work for the media, just as those who work in other social fields, are also facing challenges of a new age.
\end{abstract}

Key words: globalization, media, economy, propaganda, media conglomerates

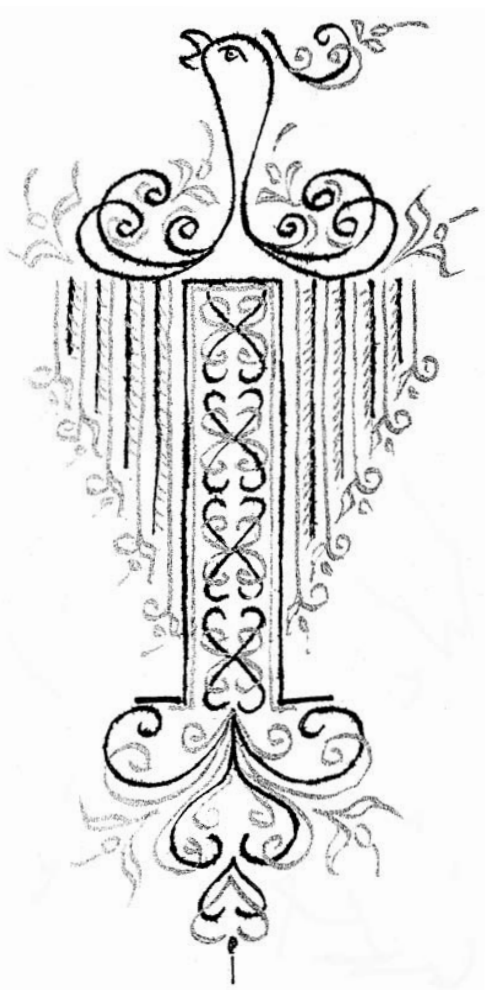

